Kamil Pietrowiak

Uniwersytet Gdański

\title{
Relacja, zobowiązanie, współpraca. Założenia i wyzwania badań etnograficznych wśród osób niewidomych
}

$\mathrm{N}^{2}$ a początku pozwolę sobie na osobiste wyznanie. Otóż od pewnego czasu czuję wyraźną nieufność, a nawet niechęć wobec kategorii antropologicznego czy etnograficznego "terenu”. Wynika to z dwojakich doświadczeń. Po pierwsze, podczas kilkuletnich badań, które prowadziłem w ramach studiów doktorskich, okazała się ona nieadekwatna do przyjętych założeń oraz przebiegu pracy. Skoro bowiem od momentu planowania badań aż do promocji książki (Pietrowiak 2019) byłem w stałym kontakcie z ich uczestnikami i uczestniczkami, to na jakiej podstawie można by wyznaczyć czytelną granicę między „byciem w terenie" a pozostałymi etapami procesu badawczego? Po drugie, zauważyłem, że podczas udziału w różnego rodzaju pozaakademickich projektach badawczych - zleconych przez firmy lub instytucje - zupełnie nie posługuję się tym pojęciem. Okazuje się, że w praktyce nie jest ono ani potrzebne, ani pomocne, nie zapewnia lepszego rozumienia założeń czy celów danego przedsięwzięcia, mało tego - zupełnie nie przychodzi na myśl.

Stąd też poczucie, że kategoria "terenu” nie opisuje mojej praktyki badawczej, nie oddaje jej specyfiki. Odbieram ją raczej jako narzuconą z zewnątrz, funkcjonującą przede wszystkim w obrębie dyskursu akademickiego, „doklejaną” do organicznego splotu myśli, relacji i sytuacji, który stanowi o dynamice badań antropologicznych czy społecznych. Owszem, stosuję ją we wnioskach, publikacjach czy raportach, ale najczęściej po to, by zapewnić uczonych czytelników - członków komisji czy recenzentów - o znajomości reguł gry, w której uczestniczymy, uprawomocnić moje działania jako naukowe, wymagające trudu i umiejętności. Choć bowiem pojęcie "terenu” w założeniu odnosi się do etnograficznego konkretu 
i trzyma nas przy ziemi, ostatecznie okazuje się zupełnie rozmyte, wszechobejmujące (Fatyga 2011). Potrafi zmieścić w sobie wszelkie zdarzenia, stany i aktywności - zarówno etnografa czy etnografki, jak i uczestników badań (Rakowski 2011: 142). Staje się tak bardzo elastyczne, że podporządkowuje się dowolnym definicjom i interpretacjom.

Z tej przyczyny - jeśli nie jestem do tego zmuszony akademickim obowiązkiem czy obyczajem - wolę myśleć i mówić o praktyce badawczej za pomocą innych metafor i kategorii. Mniej specjalistycznych, niestwarzających wrażenia eksperckości, bardziej poręcznych, czerpiących z zasobu codziennych doświadczeń. Po pierwsze, postrzegam badania etnograficzne - czy szerzej, badania jakościowe - przede wszystkim jako przestrzeń spotkania z osobami, które stały się ich uczestnikami. W tym wypadku nie ma znaczenia, jakie są cele, metody i założenia badań, ich czas trwania, wykorzystane media komunikacji, sposób prezentacji wyników. Najważniejszy jest fakt znalezienia się przed daną osobą czy grupą w roli badacza lub badaczki, a zatem kogoś, kto przychodzi z konkretną sprawą i nastawieniem. Po drugie, aktywność badawczą traktuję jako pewien tryb uważności i otwartości wobec wybranego wycinka ludzkiej rzeczywistości - zarówno względem spotykanych osób, ich słów, działań i otoczenia, jak również ogólniej - wobec danego tematu czy problemu, który stał się przedmiotem zawodowego zainteresowania etnografa czy etnografki, a co za tym idzie, wszelkich związanych z tym tropów badawczych, lektur, intuicji czy wątpliwości (por. Halemba 2011).

Takie podejście do praktyki badawczej pozwala rozumieć ją jako jeden z wielu ludzkich i międzyludzkich sposobów bycia, myślenia i działania, niemający w sobie wiele z tajemnej, niemożliwej do zwerbalizowania sztuki (por. Rakowski 2009: 34), a zamiast tego podlegający bardzo ogólnym mechanizmom i zależnościom - celom, umiejętnościom, potrzebom, oczekiwaniom i emocjom każdej ze stron biorących udział w tym procesie (Buber 1992: 141; Tischner 1998: 18, 285-288). Korzystając z zaproszenia do niniejszego tomu, prześledzę pod tym kątem jedno z moich najważniejszych doświadczeń etnograficznych, a mianowicie badania dotyczące życia osób niewidomych od urodzenia lub wczesnego dzieciństwa, które prowadziłem w latach 2011-2017. Jak sądzę, to dobra okazja do podsumowania tej pracy, a także ukazania prostoty, dostępności i elastyczności praktyki badawczej, która może stanowić zaproszenie do wspólnego tworzenia i działania.

Do środowiska osób niewidomych trafiłem w pewnym sensie bocznymi drzwiami. Nie studiowałem pedagogiki specjalnej czy tyflopedagogiki, nie byłem wcześniej wolontariuszem bądź asystentem osób niepełnosprawnych, nie miałem też niewidzących znajomych lub krewnych (por. Belzyt 2012). Wszystko zaczęło się od udziału w studencko-doktoranckim projekcie Fonosfera, w ramach którego rozważaliśmy - i testowaliśmy w działaniu - tematy wpisujące się w ogólnie pojętą antropologię zmysłów. Idąc tym tropem, trafiliśmy do wrocławskiego ośrodka szkolno-wychowawczego dla uczniów niewidomych i niedowidzących. Bez wyraźnych założeń, z ogólnymi pomysłami na wspólną zabawę, z ciekawością wobec nieznanego. 
Na miejscu okazało się, że nie byliśmy jedynymi, którzy - jak to wyraziła jedna z wychowawczyń - „potrzebują czegoś od ich dzieci”. To jednak odróżniało nas od innych „petentów”, że nasze spotkania nie miały na celu wypełnienia ankiet badawczych czy wpisania uczniów na listę kolejnego projektu aktywizującego osoby niepełnosprawne. Zamiast tego chcieliśmy zwyczajnie spotkać się z nimi, posłuchać ich historii, wspólnie spędzić czas. Trudno określić te działania mianem badań - była to raczej ciekawa przygoda, odskocznia od nie zawsze inspirujących zajęć i tekstów zadawanych w trakcie studiów, możliwość wykroczenia poza wąsko pojmowaną antropologię.

Zaciekawiony usłyszanymi historiami i zaobserwowanymi wydarzeniami zdecydowałem się na rozpoczęcie samodzielnych badań etnograficznych na temat młodych osób niewidomych. Co istotne, od tego momentu nasze interakcje nabrały wyraźnego celu - było nim napisanie rozprawy doktorskiej na temat życia osób, które zechciały wziąć udział w tym przedsięwzięciu i tym samym stać się głównymi bohaterami planowanej pracy. Wpłynęło to także na dynamikę i układ dalszych zdarzeń i relacji - nieformalne, towarzyskie spotkania, podczas których nasze role nie były jasno wyznaczone, przemieniły się w sytuacje badawcze służące $\mathrm{w}$ znacznym stopniu zebraniu wiedzy i opowieści, dokładnemu poznaniu rozmówców, pogłębianiu wybranych wątków.

Choć przyjąłem wyraźnie ukierunkowaną rolę badacza - to znaczy kogoś, kto pyta, obserwuje, chce poznać, zrozumieć i opisać - to jednocześnie od początku starałem się redukować sztuczność i nierówność tak zdefiniowanej relacji. Z tego powodu przyjąłem dewizę Jacka Olędzkiego (1991: 15), wedle której: „[...] badając innych, badam siebie. Badając innych, pozwalam na nieskrępowaną ingerencję również w moje zachowania, zajęcia i zainteresowania". Mówiąc inaczej, nie chciałem traktować mojej zawodowej pozycji jako bezpiecznej kryjówki czy też osłony dla własnej intymności i szczerości. Nie oznaczało to jednak nachalnego ekshibicjonizmu - podobnie jak uczestnicy i uczestniczki badań otwierałem się stopniowo, w swoim tempie, w zależności od poszczególnych relacji i wydarzeń. Starałem się nie mówić ani nie robić rzeczy, które stały w sprzeczności z moimi potrzebami czy emocjami, nawet jeśli - najprawdopodobniej - przyniosłoby to korzyści w postaci dodatkowych danych. Wolałem zatrzymywać się w momencie, kiedy jeszcze wiedziałem, kim jestem - kiedy mogłem rozpoznać się we własnych słowach i czynach (por. Wyka 1993: 59-60).

Ważną konsekwencją przyjęcia tej postawy było również zaproszenie rozmówców i rozmówczyń do kształtowania oraz komentowania samych badań określania problemów badawczych, nadawania kierunku szczegółowym poszukiwaniom, wspólnego pisania tekstów (Pietrowiak, Tworkowska, Zdobylak 2013), oceniania pisanych przeze mnie artykułów, a w końcu ostatecznych wyników przedstawionych w rozprawie doktorskiej. Co ciekawe, w trakcie badań dołączyła do tego kolejna, niezaplanowana przeze mnie, forma współdziałania, a mianowicie wspólne prowadzenie wykładów oraz warsztatów dotyczących tematyki niewidzenia czy niepełnosprawności, organizowanych we współpracy z instytucjami kultury czy organizacjami pozarządowymi. 
Inspiracją dla tych rozwiązań były koncepcje etnografii opartej na współpracy (collaborative ethnography) Luke'a Lassitera (2005) oraz badań społecznych przez wspólne doświadczenie Anny Wyki (1993). Mimo odmiennych punktów wyjścia oraz tradycji metodologicznych i teoretycznych, autorzy zgodnie zachęcają do otwierania się na głosy i działania uczestników i uczestniczek badań, do dawania im możliwości kształtowania przebiegu i rezultatów pracy, słowem - do traktowania ich jak równoprawnych współtwórców procesu badawczego.

Tak sformułowana propozycja opiera się na ogólniejszych założeniach etycznych i poznawczych, które określają charakter relacji i zależności między etnografem lub etnografką a osobami zaproszonymi do udziału w badaniach. Chodzi przede wszystkim o przekonanie dotyczące równoważności ich wiedzy i doświadczeń, a także - przynajmniej w pewnym stopniu - możliwości krzyżowania się ich perspektyw oraz wzajemnego zrozumienia (Wyka 1993: 50; por. Buliński, Kairski 2011: 294-295; Field 2008: 42). W tym sensie profesjonalny zasób antropologicznych pojęć i etnograficznych umiejętności nie zapewnia lepszego czy bliższego prawdy poznania rzeczywistości opisywanych ludzi. Zamiast tego jest jednym z wielu sposobów opowieści o ich życiu, uzależnionym od różnego rodzaju czynników: jakości relacji z uczestnikami badań, stopnia zaufania i zażyłości, umiejętności narracyjnych i interpretacyjnych każdej ze stron, również od celu i formy publikacji (por. Rabinow 2010: 129).

Otwieranie etnografii na uczestników i uczestniczki badań - a także innych pozaakademickich odbiorców - wymaga jednak nie tylko przeformułowania ról i relacji w obrębie procesu badawczego. Równie ważne jest udostępnienie im wyników pracy, najlepiej zaś przygotowanie ich w przystępnej formie, która będzie możliwa do przyswojenia bez znajomości antropologicznego żargonu i aktualnie modnych teorii (Foley, Valenzuela 2009: 324-325; Lassiter 2005: 19). Bez podobnego założenia etnograficzny dialog z poznanymi osobami urywa się w momencie zakończenia wywiadów i obserwacji, czy właśnie - opuszczenia "terenu" i powrotu badacza czy badaczki do „własnego", „normalnego" życia. W tym sensie troska o dostępność tekstów antropologicznych jest kolejną próbą przełamania wspomnianej postawy i umiejscowienia procesu badawczego w jednej - tej samej - rzeczywistości, która stanowi podstawę kolejnych spotkań, dyskusji i konfrontacji (Wyka 1993: 50). Jeśli bowiem rozmówcy i rozmówczynie nie mają szansy na zapoznanie się z raportem $\mathrm{z}$ badań - czy to z powodu bariery językowej, czy też braku takiej inicjatywy ze strony autorki czy autora - stają się jedynie przedmiotami procesu naukowego, nawet jeśli w trakcie spotkań byli traktowani w sposób podmiotowy i partnerski.

W moim odczuciu to właśnie etap opracowywania wyników badań był jednym z najtrudniejszych elementów wybranej strategii badawczej. Wynikało to $z$ podwójnego, zawodowego i osobistego, zobowiązania, wynikającego z jednej strony z usytuowania na określonym szczeblu akademickiej hierarchii i podległości wobec oceny komisji doktorskiej, z drugiej zaś - z powinności względem bohaterów i bohaterek rozprawy, którzy z założenia mieli stać się jej pierwszymi czytelnikami i komentatorami. Praca nad samym tekstem wymagała zatem 
ciągłego balansowania między wymaganiami stawianymi dysertacjom naukowym - a zatem wpisywania się w określone ramy i zasady gry - a moralnym zobowiązaniem wobec spotkanych osób, które mogły poczuć się oszukane po otrzymaniu hermetycznego, nieczytelnego dla nich opracowania.

Dodatkowo, jako że uczestnicy i uczestniczki badań byli faktycznymi - a nie tylko hipotetycznymi (por. Bloch 2011: 230-231) - odbiorcami rozprawy, tego rodzaju konfrontacja mogła doprowadzić do realnych konfliktów czy pretensji, wynikających choćby z poczucia, że ukazałem ich osoby w niekorzystnym świetle (por. Hammersley, Atkinson 2000: 266). Z tego powodu po ukończeniu transkrypcji nagranych rozmów wysłałem do nich wybrane fragmenty ich wypowiedzi, które planowałem zacytować w publikacji. Poprosiłem przy tym o wyraźne zaznaczenie, które z owych cytatów mam zamieścić pod ich własnymi imionami, które natomiast przy wołać z zachowaniem zasady pełnej anonimowości, to znaczy zmieniając nie tylko imiona rozmówców i rozmówczyń, ale też inne wrażliwe dane czy charakterystyczne szczegóły opowieści umożliwiające ich rozpoznanie. W przypadku braku odpowiedzi decydowałem się na samodzielne określanie stopnia anonimowości poszczególnych cytatów, chcąc uniknąć w ten sposób możliwej krzywdy rozmówców, na przykład nieprzyjemnych komentarzy ze strony innych przedstawicieli środowiska osób niewidomych.

Takie rozwiązania miały na celu nie tylko zachowanie uczciwości wobec rozmówców, ale także własnej niezależności i uważności badawczej, co w tym kontekście oznacza przede wszystkim swobodę i rzetelność podczas pisemnej interpretacji ich praktyk, poglądów i strategii. Zgadzam się bowiem, że największymi zagrożeniami dla tak uprawianej etnografii są cenzura oraz autocenzura badacza czy badaczki, spowodowane psychicznymi naciskami ze strony opisywanych ludzi, obawą przed utratą ich zaufania czy nawet zgody na udział w badaniach, chęcią ukazania pozytywnego wizerunku danej grupy (por. Lassiter 2008a: IX; 2008b: 2). W związku z tym nie przyjąłem zasady Lassitera (2004: 21), według której należy przedstawiać uczestników i uczestniczki badań w taki sposób, w jaki sami chcą być przedstawieni. Zamiast negocjować wspólną wersję tekstu, postanowiłem zatem umożliwić im komentowanie moich wniosków i spostrzeżeń, w tym wyrażanie krytycznych uwag i dopowiedzeń, które miały zostać zmieszczone na końcu poszczególnych części. W moim odczuciu takie rozwiązanie pozwoliło oddać im „ostatnie słowo” i wyrazić ewentualne zastrzeżenia względem pracy, mnie zaś - sformułować możliwie uczciwą wersję opisu, zgodną z własnymi obserwacjami i wnioskami.

Oprócz uczciwości wobec uczestników i uczestniczek badań zależało mi także na otwartości względem innych osób niewidzących, a dokładnie - na możliwie szybkim udostępnieniu im książki oraz poznaniu ich opinii i spostrzeżeń po lekturze. W związku z tym przygotowałem tekst w wersji odpowiedniego, możliwie uniwersalnego pliku elektronicznego, który - za zgodą wydawnictwa - przesłałem do Działu Zbiorów dla Niewidomych Głównej Biblioteki Pracy i Zabezpieczenia Społecznego. Dołączyłem do niego krótkie zaproszenie, skierowane bezpośrednio do użytkowników biblioteki, podając przy tym mój adres mailowy, na który mogli 
wysyłać swoje ewentualne komentarze. Tą drogą otrzymałem kilkanaście listów od niewidzących czytelników i czytelniczek, którzy najczęściej odnosili się do wybranych wątków, a także dzielili się własnymi opowieściami i wspomnieniami, dotyczącymi między innymi pobytu w ośrodku specjalnym czy szkole masowej, żmudnego poszukiwania pracy czy walki o odzyskanie wzroku.

Warto dopowiedzieć, że moje relacje z poszczególnymi uczestnikami i uczestniczkami badań nie zakończyły się w momencie obrony rozprawy doktorskiej. Wynikało to nie tylko z rodzaju zażyłości i koleżeństwa, jakie narodziły się między nami przez lata znajomości. Co bowiem istotniejsze w kontekście etnograficznej współpracy, od początku było dla mnie oczywiste, że w razie publikacji książki zaproszę ich do udziału w ewentualnych działaniach promocyjnych. Ostatecznie udało się tego dokonać $\mathrm{w}$ trzech przy padkach - w dwóch wywiadach radiowych ${ }^{1}$ oraz jednym spotkaniu autorskim ${ }^{2}$ - podczas których mogliśmy opowiedzieć o badaniach i ich rezultatach z różnych perspektyw. Niezwykle miłym zaskoczeniem, a zarazem kolejnym potwierdzeniem możliwości tego rodzaju etnografii, był dla mnie fakt, że niektórzy bohaterowie książki sami zamieszczali informację o niej na swoich profilach internetowych lub grup dla osób niewidzących.

Tyle o mnie - o moich założeniach i wyobrażeniach. Jak jednak cały proces badawczy wyglądał od strony jego uczestniczek i uczestników? Nie chcąc po raz kolejny trudzić ich prośbą o komentarz, poszukam odpowiedzi na to pytanie $\mathrm{w}$ naszych dotychczasowych rozmowach - prowadzonych zarówno w okresie trwania badań, jak i po ich zakończeniu - a także w ich wypowiedziach na temat poszczególnych części książki.

Co nietrudno przewidzieć, rozumienie idei naszych spotkań oraz rodzaju relacji zależało od wielu czynników - indywidualnych oczekiwań i zainteresowań, wcześniejszych doświadczeń związanych z udziałem w badaniach społecznych, stopnia współgrania naszych osobowości i charakterów. Mówiąc najogólniej, przypisywane mi znaczenia i motywacje rozciągały się od postaci (kolejnego) wolontariusza czy asystenta, który w zamian za udział w wywiadach oferował swoją pomoc podczas poruszania się po mieście czy załatwiania różnego rodzaju spraw; poprzez figurę doktoranta czy naukowca, mającego prawdopodobnie dobre intencje, będącego jednak człowiekiem „,z innego świata", wobec którego należy zachować odpowiednią ostrożność; aż do osoby dobrego znajomego czy kolegi, z którym można miło spędzić czas, przy okazji współtworząc pracę o "prawdziwym” życiu osób niewidomych.

${ }^{1}$ Wspólny z Aleksandrą Bohusz udział w audycji Skarbiec Nauki Polskiej w Programie 2 Polskiego Radia (link do audycji: https:/ / www.polskieradio24.pl/8/650/Artykul/2402166,Zycie-codzienne-osob-niewidzacych); wspólny z Emilią Stalmach udział w audycji OFF Czarek w radiu Tok FM (link do nagrania: https://audycje.tokfm.pl/podcast/83402,-Wystarczy-ze-mezczyzna-dobrze-pachnie-i-dotyka).

2 Wspólny z Piotrem Frańkiem udział w spotkaniu „Wielogłos o monografiach” w siedzibie Fundacji na rzecz Nauki Polskiej. 
Miłosz: Teraz widzimy cię czwarty raz. Ostatnio mówiliśmy, że musimy się kiedyś spotkać, a potem to się wszystko rozmyło. Jakbyś dziś nie musiał nagrać wywiadu, to też pewnie przyszedłbyś później, może za pół roku, może wcale.

Klaudia: Może rzeczywiście nie chcę się rozczarować, że traktuję naszą relację jako koleżeńską, a ty jesteś sprawny i masz swoich kolegów. Albo okaże się, że jak robisz jakieś badania, to jest fajnie, ale jak już tych badań nie ma, to znajomość się kończy.

Gabriela: Tak, jest tu jakaś symetria. Ja się często pytam o Kasię [moją partnerkę K.P.], o różne rzeczy z wami związane. Są rzeczy intymne, prywatne, osobiste, których bym z tobą nie poruszyła, gdyby nie ten rodzaj zażyłości, więzi - pozwolę sobie na te słowa - która się między nami wytworzyła. Ten poziom został już osiągnięty i dlatego pozwalam sobie mówić ci o wielu rzeczach. Mam do ciebie zaufanie jako do kogoś, kto mnie rozumie i nie będzie plotkował na mój temat.

Emilia: Ja tego nie rozróżniam na sferę badań i niebadań. Podoba mi się sama relacja z tobą. Lubię z tobą spędzać czas niezależnie od tego, czy ten dyktafon jest włączony, czy nie. Nie mam takiego rozróżnienia, że teraz robimy badania, a teraz idziemy gdzieś towarzysko. Dla mnie to jest jedno. Lubimy się, spotykamy się, gadamy sobie o różnych rzeczach, a przy okazji coś nagrywamy, żeby w przyszłości to pomogło nam coś razem stworzyć.

Jak okazało się w praktyce, pewnym wyzwaniem dla części rozmówców i rozmówczyń była niejednoznaczność mojej roli, a także nieformalny charakter naszych spotkań, które nie miały atmosfery wywiadu czy ankiety, lecz raczej luźnej, acz jasno ukierunkowanej rozmowy na temat ich życia. Z jednej strony, trudno było im umiejscowić mnie w świadomości jako badacza, ponieważ moja otwartość oraz intensywność naszych relacji znacznie odbiegała od ich dotychczasowych doświadczeń i przyzwyczajeń, które wiązały się z udziałem w różnego rodzaju badaniach ankietowych, realizowanych najczęściej przez studentów pedagogiki czy psychologii. Z drugiej strony, nie potrafili spojrzeć na mnie jak na swego kolegę, gdyż - co sam przypominałem im regularnie - ważnym celem tych spotkań było dla mnie zebranie informacji na temat życia osób niewidzących, nie zaś jedynie miłe czy ciekawe spędzenie wspólnego czasu.

Katarzyna: Jeśli miałabym jakoś określić naszą relację, to mówiąc szczerze, nie wiem dokładnie, jak ja cię w końcu traktuję. Jakoś tak strasznie mi się pomiksowałeś. Lubię cię. Wkurzasz mnie, jak czasami zadajesz pytania, z którymi nie wiem, co zrobić. I wtedy się trochę denerwuję. Wiem, że jak przychodzisz i mnie nagrywasz, to nie jest już taka towarzyska pogadanka. Ale generalnie nie jestem wtedy sztywna. Na początku robiło to mi różnicę, czy to nagrywałeś, czy nie. Teraz już chyba jest mi to obojętne. Przyzwyczaiłam się. Kiedyś dzieliłam nasze spotkania na „biznesowe” i prywatne. Ale teraz już wiem, że nie warto, że to bez sensu. Ty i tak możesz wykorzystać w pracy to, co mówię ci prywatnie, jeśli wyda ci się to ciekawe. 
W niektórych sytuacjach próby zniesienia tej dwoistości przybrały niespodziewane dla mnie formy, jak choćby w przypadku Lidii, która postawiła mi jasny warunek dalszej współpracy:

Lidia: Kamil, ja jestem w stanie dla przyjaciół zrobić wszystko. Ja przyjaźń traktuję bardzo poważnie, tak jak miłość prawie. Czyli powiedzmy, że jesteśmy przyjaciółmi. Jeżeli chcesz, to mogę ci wszystko powiedzieć o sobie, ale pod warunkiem, że naprawdę chcesz być moim przyjacielem. Ja się nie narzucam. Mówisz „nie” i tak nie jest.

Było dla mnie równie wielkim zaskoczeniem, że tego rodzaju wątpliwości oraz związana z nimi potrzeba oswojenia mojej osoby - tkwiły w poszczególnych rozmówcach nawet po kilku latach naszych znajomości, kiedy byłem już przekonany o trwałości naszego wzajemnego zaufania:

Joanna: Na koniec takie ostatnie spostrzeżenie. Gdy w ostatnim czasie widywaliśmy się, zastanawiałam się, czy przychodzisz na wspólne spotkania, na przykład do Muzeum Współczesnego, jako badacz, kolega czy obserwator?

Patrycja: Czytając ten rozdział, miałam też sporo różnych emocji. Dużo mówisz o byciu z niewidomymi w różnych sytuacjach, niejednokrotnie prywatnych, uzasadniając, że takie podejście pracuje na uzyskanie pełniejszego materiału badawczego. Jak najbardziej to rozumiem, ale poza badaniami istnieją relacje czysto międzyludzkie. W tym kontekście znowu powróciły do mnie pytania: Jak traktujesz naszą znajomość? Jak będzie się ona kształtowała po napisaniu przez Ciebie pracy? Oczywiście to zależy od obu stron, ale najważniejsze są intencje. Myślę, że kiedyś na ten temat pogadamy przy okazji prywatnego spotkania.

Podobne zróżnicowanie dotyczyło reakcji na moje zaproszenie do współtworzenia badań - wspólnego wyznaczania ich kierunku, czytania i komentowania wyników. Dla części osób tak sformułowana propozycja okazała się zupełnie nieczytelna lub nieatrakcyjna. $W$ takich przypadkach nasze spotkania i relacje przyjęły charakter właściwy dla klasycznych badań etnograficznych - nie straciły na swej regularności i intensywności, jednak były pozbawione tego rodzaju inicjatywy i zaangażowania ze strony ich uczestniczek i uczestników, które są niezbędne dla rozpoczęcia faktycznej, partnerskiej współpracy.

Niektóre osoby podejmowały próby "głębszego" wejścia w proces kształtowania pracy, jednak ostatecznie nie odnalazły się w zaproponowanej przeze mnie formule, a z czasem zupełnie zrezygnowały $\mathrm{z}$ udziału $\mathrm{w}$ badaniach oraz utrzymywania dalszego kontaktu.

Martyna: Wczoraj usiadłam do Twojej pracy, jednak niestety nie dotrwałam do końca, zmęczyło mnie jakoś czytanie tego naukowego języka. Nie natrafiłam póki co na żadną wzmiankę na swój temat. Nie wiem, jakiego komentarza ode mnie 
oczekujesz, a ewentualnej wzmianki o sobie nie mogę skomentować, bo ślęcząc nad Twoją pracą trzy godziny i starając się zrozumieć jak najwięcej, nie natrafiłam na wzmiankę dotyczącą mnie. Nie wiem, czy w ogóle takowe wzmianki tam są. Nie wiem też, czy mam ochotę je czytać, dotyczą najpewniej okresu w moim życiu, kiedy byłam inną osobą, z inną sytuacją życiową. Po prostu teraz czytanie tego, co było trzy lata temu, mogłoby mnie zbyt wiele kosztować.

Tym samym idea etnograficznej współpracy urzeczywistniła się dzięki zaangażowaniu 13 spośród 22 zasadniczych uczestników i uczestniczek badań, którzy włączyli się do współtworzenia pytań badawczych i komentowania zarówno wstępnych, jak i ostatecznych wyników pracy. Motywacje poszczególnych osób były różne - jedni dostrzegli w tym możliwość rozwoju swoich humanistycznych zainteresowań, inni szansę na wygłoszenie własnych przekonań i postulatów.

Sandra: Gdy zapytałeś mnie na początku, o czym warto napisać taką pracę na temat niewidomych, pomyślałam: „I co? Całą robotę będę musiała zrobić za niego?! Już wolę, jak studenci przychodzą z gotowymi kwestiami i przepytują mnie krok po kroku". Ale później pomyślałam, że to daje motywację do mówienia, bo masz świadomość, że możesz jakoś wpłynąć na tę pracę, że jesteś tu aktywny, kreatywny.

Emilia: Ty jesteś po prostu moim kolegą, z którym coś razem robimy. W porządku, to ty wysunąłeś pomysł tych badań, ale to, co tutaj robimy, jest w równym stopniu ważne. Robimy wspólną rzecz, strzelamy do jednej bramki.

Joanna: Ważna jest kwestia postrzegania osób niewidomych przez innych ludzi. Trzeba uczulić czytelnika, że osoby niewidome poznają świat $\mathrm{w}$ trochę inny sposób, ale że to nie jest wzięte $z$ kosmosu, totalnie odmienne. Bo ja niestety mam takie wrażenie, że to często tak się kojarzy widzącym. Chciałabym, aby ludzie postrzegali środowisko niewidomych jako coś zupełnie normalnego, zwykłego. Jeśli osoby pełnosprawne różnią się czymś między sobą, to tego aż tak się nie widzi, na to nie zwraca się uwagi. A przecież oni też się różnią, mają inne temperamenty, inne osobowości, inne sposoby patrzenia. Dobrze, gdyby ludzie dowiedzieli się, że niewidomi są w dużym stopniu takimi samymi osobami jak oni, jak reszta. Trzeba zmieniać stereotypy.

Mimo odmiennych potrzeb i celów, osoby, które zechciały zaangażować się w kreowanie procesu badawczego, łączył pewien zbiór cech - otwartość, ciekawość, chęć działania, umiejętność opowiadania o swoich emocjach, poglądach i doświadczeniach. W tym sensie wymienione atrybuty pozwalają na zaistnienie faktycznej - a nie tylko iluzorycznej czy deklaratywnej - etnograficznej współpracy. Jednocześnie jednak odsłania to wyraźne ograniczenie tak ukierunkowanych badań, które niejako z założenia zagłuszają głos mniej aktywnych czy „przebojowych” przedstawicieli danej grupy. Tak też stało się w opisywanym 
przypadku - wystosowana przeze mnie propozycja mimowolnie zwęziła grupę badawczą do osób w znacznym stopniu samodzielnych, dążących do życiowej niezależności, pracujących. $W$ efekcie przedstawiony przeze mnie opis koncentruje się na ich życiowych strategiach i praktykach, jedynie w niektórych miejscach odnosząc się do sytuacji mniej samodzielnych osób niewidzących, często bezrobotnych, biernych, uzależnionych od rodziców lub partnerów, spędzających większość czasu w domu lub na warsztatach terapii zajęciowej.

Co zatem widzę, kiedy patrzę na ten proces po zakończeniu badań i publikacji ich ostatecznych wyników? Czy dostrzegam coś nowego, co przeoczyłem $\mathrm{w}$ trakcie ich prowadzenia? Po pierwsze, widzę wokół siebie kilka naprawdę bliskich mi osób, z którymi mam regularny kontakt oraz bardzo intymny rodzaj porozumienia. Po drugie, najbardziej namacalną i bardzo owocną formą naszej współpracy okazały się wspólnie organizowane i prowadzone warsztaty na temat niepełnosprawności i niewidzenia. Jak sądzę, wynika to z możliwości zupełnego zrzucenia mojego naukowego "gorsetu" oraz funkcjonowania jako zupełnie równoprawni twórcy danej sytuacji, mający wspólne cele i wartości, $\mathrm{w}$ tym oswajanie tematu ślepoty w świadomości osób widzących, stwarzanie możliwości do bezpośredniego kontaktu i wzajemnego poznania. Po trzecie, ważną nagrodą za przyjętą przeze mnie postawę - zarówno badawczą, jak i etyczną - stało się zaufanie ze strony innych, nieznanych mi wcześniej osób niewidomych, okazywane zarówno $\mathrm{w}$ prywatnych mailach, komentarzach na Facebooku, jak i podczas bezpośrednich rozmów na spotkaniach autorskich. Po czwarte wreszcie, dzięki przebyciu tej drogi przekonałem się o mocy pogłębionych i długotrwałych badań etnograficznych, które - nawet jeśli opierają się na relacjach z kilkunastoma czy kilkudziesięcioma osobami - mogą odsłonić ogólniejsze problemy czy wyzwania pozostałych przedstawicieli danej grupy. Cóż bowiem może być większym potwierdzeniem wartości naszej dyscypliny, jak nie słowa niewidomej czytelniczki, która powiedziała po jednej z dyskusji na temat książki: „Ta książka jest prawdziwa. Ona jest o mnie”.

\section{Literatura}

Belzyt, J. (2012). Niepetnosprawność - Edukacja - Dorosłość. Studium przypadku osoby ociemniałej. Kraków: Oficyna Wydawnicza Impuls.

Bloch, N. (2011). Teren a władza, czyli kto tu rządzi? Moje doświadczenia w badaniu uchodźców tybetańskich. W: T. Buliński, M. Kairski (red.), Teren w antropologii. Praktyka badawcza we wspótczesnej antropologii kulturowej (209-235). Poznań: Wydawnictwo Naukowe UAM.

Buber, M. (1992). Ja i Ty. Wybór pism filozoficznych. Przeł. J. Doktór. Warszawa: PAX.

Buliński, T., Kairski, M. (2011). Wiedza terenowa w antropologii. W poszukiwaniu nowego wymiaru badań terenowych. W: T. Buliński, M. Kairski (red.), Teren w antropologii. Praktyka badawcza we współczesnej antropologii kulturowej (291-333). Poznań: Wydawnictwo Naukowe UAM. 
Fatyga, B. (2011). Teren po horyzont (poznawczy). W: T. Buliński, M. Kairski (red.), Teren $w$ antropologii. Praktyka badawcza we wspótczesnej antropologii kulturowej (s. 93-110). Poznań: Wydawnictwo Naukowe.

Foley, D., Valenzuela, A. (2009). Etnografia krytyczna. Polityka współpracy. Przeł. M. Bobako. W: N.K. Denzin, Y.S. Lincoln (red.), Metody badań jakościowych, t. 1 (s. 315339). Warszawa: PWN.

Halemba, A. (2011). Polityka, teoria i metoda - czyli co tworzy współczesną antropologię. W: T. Buliński, M. Kairski (red.), Teren w antropologii. Praktyka badawcza we współczesnej antropologii kulturowej (s. 111-130). Poznań: Wydawnictwo Naukowe UAM.

Lassiter, L.E. (2004). Introduction: The Story of a Collaborative Project. W: L.E. Lassiter $\mathrm{i}$ in. (red.), The Other Side of Middletown: Exploring Muncie's African American Community (s. 1-24). Walnut Creek: AltaMira Press.

Lassiter, L.E. (2005). The Chicago Guide to Collaborative Ethnography. Chicago-London: The University of Chicago Press.

Lassiter, L.E. (2008a). Editor's Introduction. Collaborative Anthropologies, 1, VII-XII.

Lassiter, L.E. (2008b). When We Disagree. On Engaging the Force of Difference in Collaborative, Reciprocal, and Participatory Researches. Artykuł zaprezentowany na 107. Dorocznym Spotkaniu American Anthropological Association, San Francisco, California,

http://www.marshall.edu/gsepd/humn/lassiter/coll_ethnography/Lassiter_AAA08_ When-We-Disagree.pdf [dostęp: 20.11.2012].

Olędzki, J. (1991). Murzynowo. Znaki istnienia i tożsamości kulturalnej mieszkańców wioski nadwiślańskiej XVIII-XX w. Warszawa: Wydawnictwa UW.

Pietrowiak, K. (2019). Świat po omacku. Etnograficzne studium (nie)widzenia i (nie)sprawności. Torun: Wydawnictwo Naukowe UMK.

Pietrowiak, K., Tworkowska, S., Zdobylak, J. (2013). Etnograficzny tandem, czyli na ślepo w nieznane. Tematy z Szewskiej, 10, 25-63.

Rabinow, P. (2010). Refleksje na temat badań terenowych w Maroku. Przeł. K.J. Dudek, S. Sikora. Kęty: Wydawnictwo Marek Derewiecki.

Rakowski, T. (2009). Łowcy, zbieracze, praktycy niemocy. Etnografia człowieka zdegradowanego. Gdańsk: słowo/obraz terytoria.

Rakowski, T. (2011). Teren, czas, doświadczenie. O specyfice wiedzy antropologicznej po zwrocie krytycznym. W: T. Buliński, M. Kairski (red.), Teren w antropologii. Praktyka badawcza we wspótczesnej antropologii kulturowej (s. 131-149). Poznań: Wydawnictwo Naukowe UAM.

Tischner, J. (1998). Filozofia dramatu. Kraków: Znak.

Wyka, A. (1993). Badacz społeczny wobec doświadczenia. Warszawa: Wydawnictwo IFiS PAN.

\section{SUMMARY}

Relationship, commitment, collaboration. Assumptions and challenges of ethnographic research among blind people

The article presents the main assumptions and conditions of collaboration between the author and the vision-impaired research participants over several years of ethnographic research (2011-2017). Adopting the perspective of philosophy of dialogue, the author follows different stages of rapport, focusing on mutual expectations and emotions, as well as relationship dynamics and its underlying conditions in general. The author's long-term 
research was inspired by concepts developed by Luke Lassiter in his collaborative ethnography and by Anna Wyka in her social research through shared experience, both of which marked the author's ethical and methodological choices, including invitation extended to research participants to comment on the research findings. The second part of the article is based on research participants' impressions and reflections on their role, engagement and relationship with the researcher.

Keywords: vision-impaired people, collaborative ethnography, research participants, ethical challenges, trust, relationship. 